\title{
Detection of Sex Pheromone Production in Isolates of Enterococcus faecalis that Increases Conjugation Frequency
}

\author{
Rayan M. Faisal \\ Department of Biology \\ College of Science \\ University of Mosul
}

Email: rayanmazin@yahoo.com

(Received 4/6/2012 ; Accepted 18/7/2012)

\begin{abstract}
Eight isolates of Enterococcus faecalis previously identified by API20 strep for Enterococci from diarrheal cases were used in the present study. Resistance towards ampicillin, cefalexin, tetracycline, chloramphenicol, gentamicin, erythromycin, streptomycin and nalidixic acid was determined and the results showed different antibiotic resistance pattern. The presence of a conjugation system in Enterococcus isolates was determined by mating with plasmid free strain of E.coli JM83, the results indicated the presence of conjugative system in isolates number 3,4,6 and 7 corresponded with the transfer of antibiotic resistance genes for cefalexin, tetracycline, gentamicin and nalidixic acid to recipient strain of E.coli JM83 at a frequency of $\left(0.24-0.55 \times 10^{-7}\right)$ which may indicate the presence of an $\mathrm{F}$ plasmid in these isolates. The ability of the Enterococcus isolates to produce sex pheromone was detected by treating the conjugation mixture of the isolates 3,4,6 and 7 with E.coli JM83 with pheromones isolated from the isolates 1,2,5 and 8 separately. The results showed the ability of the pheromone isolated from isolate 2 to increase the conjugation frequency to $\left(0.16 \times 10^{-5}\right)$ between isolate 6 and the recipient strain of E.coli JM83 which indicates the presence of a pheromone-responsive plasmid in the isolate 6 that is induced with the pheromone produced by isolate 2 .
\end{abstract}

Keywords: Sex pheromones, Enterococcus Faecalis, Conjugation.

\section{Enterococcus faecalis الكثف عن إنتاج الفيروونات الجنسية في عزلات جرثومة والتي تزبدمن تردد الغتران}

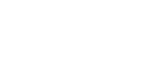

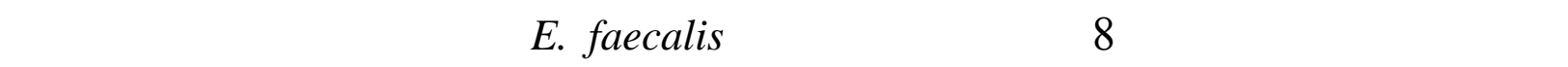
API20strep

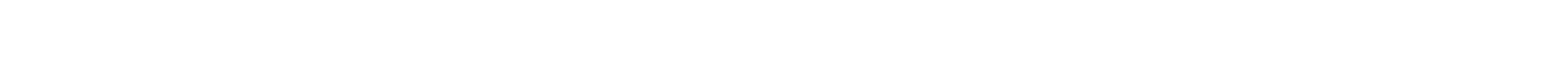


والارثرومليسن وللستربتومليسن وحلمض النالكسيك، و أوضحت النتائج ظهور تباين في مقاومة العزلات للمضادات قيد الدرلسة. حدد لمتلاك العزلات قيد الدرلسة لظلم اقتران من خلل إجراء الاقتران بينها وبين

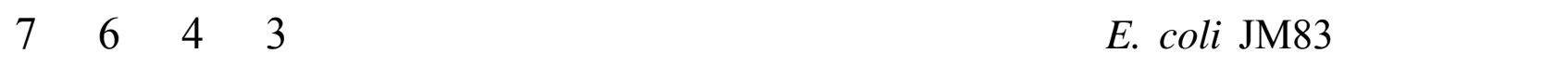
لبلازميدات الخصوبة والتي رافقها انقفل مورثلت المقاومة لمضادت للسيفالكسين والتترلسايكلين والجنتلمليسن وحلمض النالمكسيك إلى للسلالة القيلسية E. coli JM83 وتراوح تردد الاقتران بين

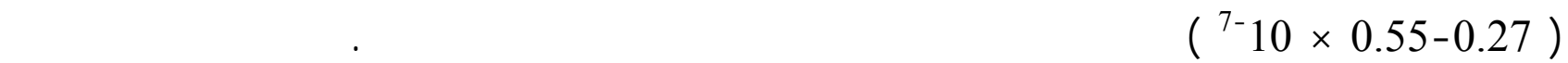
جرثاومة Enterococcus على إنتاج الفيرمونات الجنسية من خلال معلملة مزيج الاقتران للعزلات 3 و 4 و و 1 و

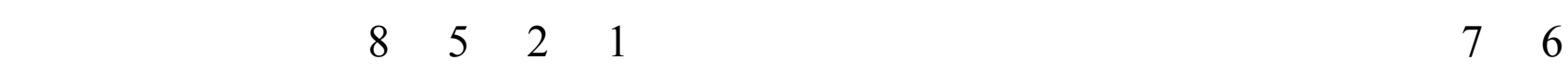

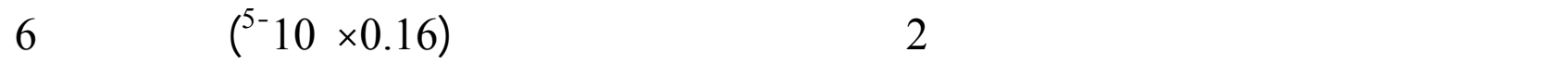
وللسلالة القيلسية E. coli JM83 مما يدل على المتلاك العزلة 6 بلازميدات مستجيبة للفيرمون يمكن تحفيزها بالفيرمون المنتج من العزلة 2.

\section{الكامل الدالة: الفيرمونت الجنسية، Enterococcus faecalis ، اقتران.}

\section{INTRODUCTION}

Enterococci are common inhabitants of the human intestinal microflora and the genitourinary tract of men and women and is also present in most animals ( Dahlen et al., 2012 ). Because of their presence in these habitants, the enterococci enter the human food chain, where they can play different and in many cases controversial roles (Borgo et al., 2009). Consequently, enterococci are well suited to survive in hospital settings, where antibiotic selective pressure is heavy. The development of high level resistance to aminoglycosides, pencillins and glycopeptides (Vancomycin and teicoplanin ) singly and in combination has important clinical implications (Leclerq, 1997). In enterococci, resistance factors are often associated with mobile genetic elements, such as transposons or conjugative plasmids, these plasmids are also capable of mobilizing smaller plasmids and this fact may explain the dissemination of smaller plasmids carrying antibiotic resistance genes among gram positive bacteria (Borgo et al., 2009). However, three different mechanisms of conjugation have been reported in enterococci differing in regulation mechanisms rather than in the actual conjugation process: pheromone - responsive plasmid, broad-host-range plasmids and conjugative transposes (Migura et al., 2009). Pheromone responsive transmissible plasmids are common among strains of Enterococcus faecalis conjugative transfer of these plasmids is induced by peptide sex pheromones elaborated by potential recipient cells. These pheromones are 7-8 amino acids long and act rapidly on donor cells containing a pheromone - responsive plasmid to elicit a specific mating response which includes an expression of a surface protein on plasmid containing cells ( called aggregation substance) that enables the donor and recipient to adhere and transfer plasmids by conjugation ( Huyck et al., 1992 ). Pheromone - induced conjugation allows plasmid transfer at high frequencies in broth $\left(10^{0}\right.$ to $10^{-4}$ per donor cell $)$, whereas non- 
pheromone plasmids are generally transferred at low frequencies $\left(10^{-8}\right.$ to $10^{-9}$ per donor cell) (Migura et al., 2009).

The aim of this research is to detect the isolates of $E$. faecalis which has the ability to produce sex- pheromones in order to detect the pheromone - responsive transmissible plasmids in other E. faecalis isolates.

\section{Bacterial strains}

\section{MATERIALS AND METHODS}

Eight isolates of Enterococcus faecalis were used. These were previously collected from diarrheal specimens in Mosul governorate and identified with API20 strip for Enterococcus Kandela et al., (2012) .

The standard strain E.coli JM83 was obtained from Dr. George M. Weinstock, Department of Biochemistry and Molecular Biology, University of Texas that carried the genetic markers ara $, \Delta(\underline{\text { lac }} \underline{\text { pro }} \mathrm{A}, \mathrm{B}), \mathrm{rpsL}, \varnothing 80$ lacZ $\Delta \mathrm{M} 15, \mathrm{Sm}^{\mathrm{R}}, \mathrm{k}^{+\mathrm{r}}, \mathrm{k}^{+\mathrm{m}}$.

\section{Antibiotic susceptibility testing}

Screening for antibiotic resistance towards Ampicillin $(25 \mu \mathrm{g} / \mathrm{ml})$, Chloramphenicol (10 $\mu \mathrm{g} / \mathrm{ml})$, Tetracycline ( $15 \mu \mathrm{g} / \mathrm{ml})$, Cefalexin $(30 \mu \mathrm{g} / \mathrm{ml})$, Gentamicin ( $20 \mu \mathrm{g} / \mathrm{ml})$, Streptomycin ( $50 \mu \mathrm{g} / \mathrm{ml}$ ), Nalidixic acid ( $30 \mu \mathrm{g} / \mathrm{ml})$ and Erythromycin ( $25 \mu \mathrm{g} / \mathrm{ml}$ )was performed using nutrient agar plates containing these antibiotics with previously mentioned concentrations as described by Grant and Pittard (1974).

\section{Pheromone detection}

Late-stationary phase cultures were obtained by inoculating $1 \mathrm{ml}$ of the overnight culture in $100 \mathrm{ml}$ of fresh BHI broth and incubated at $37^{\circ} \mathrm{C}$ with shaking to a final concentration of $5 \times 10^{8} \mathrm{cell} / \mathrm{ml}$. The culture was centrifuged at $10,000 \mathrm{rpm}$ for $10 \mathrm{~min}$ and the supernatants containing pheromones then filtered through $0.22 \mu \mathrm{m}$ filter. The filtrates were autoclaved at $121^{\circ} \mathrm{c}$ for $15 \mathrm{~min}$ and stored at $4^{0} \mathrm{C}$ prior to use as mentioned by Donelli et al., (2004).

\section{Mating experiments}

Conjugation between E. faecalis donor isolates and recipient E.coli JM83 was performed according to (Olsen et al., 1995). Transconjugants were selected on Brain Heart Infusion agar (BHI) containing two antibiotics (Nalidixic acid and Erythromycin) depending on the genotype of the donor and recipient. Transconjugants were stained with gram stain to confirm that they were E. coli JM83 cells. Conjugation was done with and without the addition of pheromones isolated from other Enterococcus isolates and conjugation frequency was recorded in both cases.

\section{Induction of Mating using collected pheromone}

One $\mathrm{ml}$ of the filtrate containing pheromone was added to the conjugation mixture (containing $0.7 \mathrm{ml}$ donor, $0.3 \mathrm{ml}$ recipient and $1 \mathrm{ml}$ nutrient broth ) as described by Lim et al., (2006) and incubated for 4 hours as done previously in the mating experiment according to Olsen et al., (1992).

\section{Antibiotic susceptibility}

\section{RESULTS AND DISCUSSION}

The clinical isolates of Enterococcus faecalis exhibited different patterns of antibiotic resistance as shown in table (1). All isolates were resistant to nalidixic acid while no 
resistance towards ampicillin was observed and different antibiotic pattern to other antibiotics were noticed.

Table 1: Antibiotic resistance pattern of isolates under study towards different antibiotics.

\begin{tabular}{|c|c|c|c|c|c|c|c|c|}
\hline \multirow{2}{*}{$\begin{array}{c}\text { Isolate } \\
\text { no. }\end{array}$} & \multicolumn{8}{|c|}{ Nutrient agar media containing different antibiotics in $(\mu \mathrm{g} / \mathrm{ml})$} \\
\hline & Ap(50) & $\mathrm{Cf}(\mathbf{3 0})$ & Tc(15) & $\mathrm{Cm}(10)$ & $\mathrm{Gm}(30)$ & $\mathrm{E}(25)$ & $\operatorname{Sm}(50)$ & NA(30) \\
\hline 1 & $\mathrm{~S}$ & $\mathrm{R}$ & $\mathrm{R}$ & $\mathrm{R}$ & $\mathrm{R}$ & $\mathrm{R}$ & $\mathrm{R}$ & $\mathrm{R}$ \\
\hline 2 & $\mathrm{~S}$ & $\mathrm{R}$ & $\mathrm{R}$ & $\mathrm{R}$ & $\mathrm{R}$ & $\mathrm{R}$ & $\mathrm{R}$ & $\mathrm{R}$ \\
\hline 3 & $\mathrm{~S}$ & $\mathrm{R}$ & $\mathrm{R}$ & $S$ & $\mathrm{R}$ & $S$ & $\mathrm{R}$ & $\mathrm{R}$ \\
\hline 4 & $\mathrm{~S}$ & $\mathrm{R}$ & $\mathrm{S}$ & $S$ & $\mathrm{R}$ & $S$ & $\mathrm{R}$ & $\mathrm{R}$ \\
\hline 5 & $\mathrm{~S}$ & $\mathrm{R}$ & $\mathrm{R}$ & $\mathrm{R}$ & $\mathrm{R}$ & $\mathrm{R}$ & $\mathrm{R}$ & $\mathrm{R}$ \\
\hline 6 & $\mathrm{~S}$ & $\mathrm{R}$ & $\mathrm{S}$ & $\mathrm{S}$ & $\mathrm{R}$ & $\mathrm{S}$ & $\mathrm{S}$ & $\mathrm{R}$ \\
\hline 7 & $\mathrm{~S}$ & $\mathrm{R}$ & $\mathrm{S}$ & $S$ & $\mathrm{R}$ & $\mathrm{S}$ & $\mathrm{R}$ & $\mathrm{R}$ \\
\hline 8 & $S$ & $S$ & $\mathrm{~S}$ & $S$ & $\mathrm{~S}$ & $S$ & $\mathrm{R}$ & $\mathrm{R}$ \\
\hline JM83 & $\mathrm{S}$ & $\mathrm{S}$ & $\mathrm{S}$ & $\mathrm{S}$ & $\mathrm{S}$ & $\mathrm{R}$ & $\mathrm{R}$ & $\mathrm{S}$ \\
\hline
\end{tabular}

S: Sensitive ; R: Resistant ; Ap: Ampicillin ; Cf: Cefalexin ; Tc: Tetracycline ; Cm: Chloramphenicol ; Gm: Gentamicin ; E:Erythromycin ; Sm: Streptomycin; NA: Nalidixic acid.

Isolates 1,2 and 5 were the most resistant to antibiotics as they were resistant to all antibiotics tested except ampicillin. Dahlen et al., (2012) also found that ampicillin and amoxicillin showed highest effect on enterococci as he found that $57.4 \%$ and $31.1 \%$ respectively, of his isolates were sensitive to these antibiotics respectively .

Our results were compatible with Donelli et al., (2004) who had only two isolates out of 19 resistant to ampicillin while most of his isolates were resistant to chloramphenicol, tetracycline and erythromycin and he also found that 6 of these isolates were multidrug resistant. On the other hand, we found that isolate 8 was resistant to 2 out of 8 tested antibiotics which could be due to lack of plasmids in this isolate. This was also mentioned by Donelli et al., (2004) as he found that plasmid DNA was absent in 7 out of 19 enterococci tested.

Our results also show that isolates 1,2 and 5 that were resistant to erythromycin were resistant to multiple antibiotics. This was noticed by Khan et al., (2002) who found that resistance to erythromycin in Enterococcus is due to the occurrence of ermB gene which may locate on a plasmid or a transposon or even on the chromosome and he found that all of his erythromycin resistant isolates were resistant to multiple antibiotics.

All of our isolates were resistant to nalidixic acid which was also noticed by Kimiran et al., (2007) who tested 24 Enterococcus isolates to 11 different antibiotic and found that all isolates were resistant to nalidixic acid.

\section{Mating experiment}

Conjugation between Enterococcus faecalis isolates and the recipient strain E.coli JM83 was performed to test for the presence of $F$ plasmid and to detect the selftransmissible plasmids in Enterococcus faecalis isolates. Differences in two selective 
markers is necessary to undergo conjugation and therefore the isolates 3,4,6,7 and 8 which were sensitive to erythromycin and resistant to nalidixic acid which is in contrast of recipient E.coli JM83, were chosen for conjugation experiment and the results were shown in table (2).

Table 2 : Conjugation frequency of Enterococcus faecalis isolates and E.coli JM83.

\begin{tabular}{|c|c|c|c|c|}
\hline \multicolumn{2}{|r|}{ E.faecalis Donar } & \multirow{2}{*}{$\begin{array}{c}\text { Recipient } \\
\text { E.coli } \\
\text { JM83 } \\
\text { antibiotic } \\
\text { resistance } \\
\text { pattern }\end{array}$} & \multirow{2}{*}{$\begin{array}{c}\text { Transconjugant } \\
\text { antibiotic resistance } \\
\text { pattern }\end{array}$} & \multirow{2}{*}{\begin{tabular}{|c} 
Conjugation \\
frequency
\end{tabular}} \\
\hline $\begin{array}{c}\text { Isolate } \\
\text { no. }\end{array}$ & $\begin{array}{c}\text { Antibiotic } \\
\text { resistance pattern }\end{array}$ & & & \\
\hline 3 & $\mathrm{Cf}^{\mathrm{R}}, \mathrm{Tc}^{\mathrm{R}}, \mathrm{Gm}^{\mathrm{R}}, \mathrm{NA}^{\mathrm{R}}, \mathrm{E}^{\mathrm{S}}$ & \multirow{4}{*}{$\begin{array}{lr}\mathrm{E}^{\mathrm{R}} & \mathrm{NA}^{\mathrm{S}} \\
\mathrm{Tc}^{\mathrm{S}} & \mathrm{Cf}^{\mathrm{S}} \\
\mathrm{Gm}^{\mathrm{S}} & \end{array}$} & $\mathrm{E}^{\mathrm{R}}, \mathrm{Cf}^{\mathrm{R}}, \mathrm{Tc}^{\mathrm{R}}, \mathrm{Gm}^{\mathrm{R}}, \mathrm{NA}^{\mathrm{R}}$ & $0.27 \times 10^{-7}$ \\
\hline 4 & $\mathrm{Cf}^{\mathrm{R}}, \mathrm{Gm}^{\mathrm{R}}, \mathrm{NA}^{\mathrm{R}}, \mathrm{E}^{\mathrm{S}}$ & & $\mathrm{E}^{\mathrm{R}}, \mathrm{Cf}^{\mathrm{R}}, \mathrm{Gm}^{\mathrm{R}}, \mathrm{NA}^{\mathrm{R}}$ & $0.55 \times 10^{-7}$ \\
\hline 6 & $\mathrm{Cf}^{\mathrm{R}}, \mathrm{Gm}^{\mathrm{R}}, \mathrm{NA}^{\mathrm{R}}, \mathrm{E}^{\mathrm{S}}$ & & $\mathrm{E}^{\mathrm{R}}, \mathrm{Cf}^{\mathrm{R}}, \mathrm{Gm}^{\mathrm{R}}, \mathrm{NA}^{\mathrm{R}}$ & $0.27 \times 10^{-7}$ \\
\hline 7 & $\mathrm{Cf}^{\mathrm{R}}, \mathrm{Gm}^{\mathrm{R}}, \mathrm{NA}^{\mathrm{R}}, \mathrm{E}^{\mathrm{S}}$ & & $\mathrm{E}^{\mathrm{R}}, \mathrm{Cf}^{\mathrm{R}}, \mathrm{Gm}^{\mathrm{R}}, \mathrm{NA}^{\mathrm{R}}$ & $0.41 \times 10^{-7}$ \\
\hline
\end{tabular}

Isolate 8 was not able to conjugate with E. coil JM83 which may reflect the absence of a conjugation system in this isolate. This supports our results previously mentioned in the poor antibiotic resistance which may indicate the lack of plasmids in this isolate.

Table (2) shows the occurrence of F plasmid in isolate 3,4,6 and 7 that had the ability to conjugate with the laboratory strain E. coli JM83 and transfer the antibiotic resistance genes they carried to transconjugant colonies. The conjugation system in Enterococcus are one of the most efficient bacterial conjugation system known as indicated by Hirt et al., (2005) as this family consists of over 20 plasmids and shows extensive sequence homologies and the species E. faecalis can host several of these plasmids.

Our results also show that all of our isolates that underwent conjugation had the ability to transfer the genes responsible for cefalexin, nalidixic acid, tetracycline and gentamycin resistance. This is compatible with Leclerq et al., (1992) as they noticed that Enterococci are highly resistant to aminoglycosides by coding aminoglycoside-modifying enzymes which is located on self-transferable plasmids. Dahlen et al., (2012) also mentioned that Enterococcus commonly contain plasmids that are exchanged between isolates of Enterococci and to medical and food bacteria via conjugation and this may be suppressed by the production of pheromones from some isolates of Enterococci. Tomita and Ike (2005) also found that the conjugative plasmid pMG1 located in Enterococcus isolates carries the gentamicin resistance gene which is transferred to transconjugants which is compatible also with our work as we have found that all transconjugants tested were resistant to gentamicin.

\section{Mating induction with pheromones}

Conjugation of the isolates which had the ability to conjugate was induced with the addition of pheromones isolated from the isolates $1,2,5$ and 8 . We found that from the four previously mentioned isolates tested isolate 2 had the ability to produce pheromones which induced the ability of the isolate 6 to conjugate with the laboratory strain E. coli JM83 at a frequency of $0.16 \times 10^{-5}$ which is about 100 times that of the frequency of the untreated isolates which was $0.27 \times 10^{-7}$ as shown in table 2 and plate 1 . 


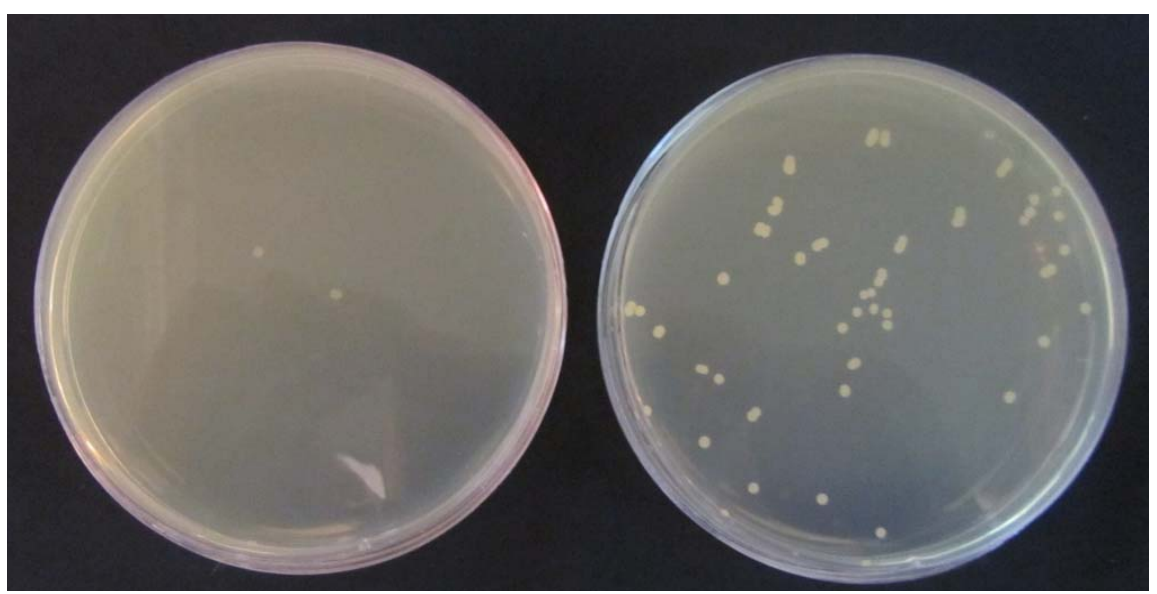

\section{Plate 1: transconjugants of isolate 6 treated with pheromone of isolate 2 (Right plate) and untreated (left plate) on BHI agar containing nalidixic acid and erythromycin.}

All transconjugants tested were resistant to erythromycin, cefalexin, gentamycin and nalidixic acid as found in the untreated isolates. Our results are compatible with those of Lim et al., (2006) as they found that the pheromone responsive plasmids pSL1 and pSL2 isolated from E. faecalis $\mathrm{kV} 1$ and $\mathrm{kV} 2$ transferred the resistance to vancomycin, gentamycin , kanamycin , streptomycin and erythromycin at a frequency of about $10^{-3}$ per donor when treated with the filterate of $E$. faecalis FA-2 culture. The plasmid did not respond to several other synthetic pheromones tested, this may indicate that isolates 1,2,5 and 8 may produce other pheromones that did not induce the transfer of plasmids in the isolates 3,4 and 7 and we can also say that the isolates 3,4 and 7 may had contained another pheromone responsive plasmid which is not responding to the pheromones isolated from the isolates $1,2,5$ and 8 . The conjugation frequency of treated isolate 6 was less than this researcher maybe because he used the ratio 1:9 donor/ recipient with the laboratory strain $E$. faecalis as a recipient strain in conjugation .

The response of isolate 6 to the pheromone produced by isolate 2 unlike other isolate tested may indicate the presence of a special regulation system in the isolate 6 that is activated or released from repression by a special pheromone that was produced by isolate 2 and not affected by others as mentioned by Hirt et al., (2005) who found that the pheromone is taken into the cell and releases a transcriptional block of the PrgX/TraA family of repressors, that is one of the early transcripts after induction encodes the surface protein aggregation substance (AS) which is responsible for the tight physical contact between donor and recipient that is necessary for conjugation frequency induction .Zheng et al., (2009) found that the complete DNA sequence of E. faecalis pMG2200 plasmid contained the regulatory region found in pheromone responsive plasmids and encoded the genes prgX and prgQ, which are the key negative regulatory elements for plasmid pCF10 and also the TraE1 a key positive regulator of plasmid pAD1.

\section{REFERENCES}

Borgo, F. ; Ricci, G. ; Arends, K. ; Schiwon, K. ; Grohmann, E. ; Fortina, M. (2009). Evaluation of plasim content and tetracycline resistance conjugative transfer in Enterococcus italicus strains of dairy origin, Current Microbiology. 59, 261-266. 
Dahlen, G.; Blomqvist, S. ; Almstahl, A. ; Carlen, A. (2012). Virulence factors and antibiotic susceptibility in enterococci isolated from oral mucosal and deep infections, J. Oral Microbiology. 4,10855-10861.

Donelli, G.; Paoletti, C. ; Baldassarri, L. ; Guaglianone, E. ; Dirosa , R. ; Magi, G. ; Spinaci, C. ; Facinelli , B. (2004). Sex pheromone response, clumping and slime production in Enterococcal strains isolated from occluded biliary strents, J. Clinical Microbiology. 42 , 3419-3427.

Grant, A. ; Pittard, J. (1974). Incompatability reactions of R plasmids isoloated from Escherichia coli of animal origin , J. Bacteriol. 120, 185-188.

Grindley, J.N. ; Grindley, N.D. ; Anderson, E. S. (1970). Acridine treatment of $\mathrm{F}^{+}$and Hfr strains of Escherichia coli k-12 carring a neomycin- kanamycin resistance determinant, Genetical Researche Cambridge. 15, 327-334.

Hirt, H. ; Manias, D. A. ; Bryan, E. M. ; Klein, J.R.; Marklund, J. K. ; Staddon , J.H. ; Paustian, M. L. ; Kapur, V. ; Dunny, G.M. (2005). Charecterization of the pheromone response of the Enterococcus faecalis conjugative plasmid pCF10: Complete sequence and comparative analysis of the transcriptional and phenotypic responses of pCF10-containing cells to pheromone induction , J. Bacteriol. 187, $1044-1054$.

Huycke, M. ; Gilmore, M. ; Jett, B. ; Booth, J.(1992).Transfer of pheromone - inducible plasmids between Enterococcus faecalis in the Syrian hamster gastrointestinal tract, J. Infectious Diseases. 166,1188-1191.

Kandela, N. Aziz , G. ; Khankah , H. (2012). A genetic study on enterocin-production from Enterococcus faecalis isolates from different clinical sources , First International Conference of Genetic Engineering, Baghdad University, Iraq.

Khan , A. A. ; Nawaz, M.S. ; Khan, S.A. ; Steele, R. (2002). Detection and characterization of erythromycin- resistant methylase genes in gram-positive bacteria isolated from poultry litter, Applied Microbiology and Biotechnology. 59,377-381.

Kimiran, A. ; Arslan, E.O. ; Yurudu, N. O. ; Zeybek, Z. ;Dogruoz, N. ; Cotuk, A.( 2007). Isolation and Identification of Enterococci from sea water samples : Assessment of their resistance to antibiotics and heavy metals, Environmental Monitoring and Assessment. 125, 219-288.

Leclercq, R. (1997). Enterococci acquire new kinds of resistance. Clinical infectious Diseases. 24,S80-S84.

Leclereq, R. ; Dutka, S. ; Brisson , A. ; Molinas, C. ; Derlot, E. ; Arthur, M. ; Duval, J. ; Courvalin, P. (1992). Resistance of Enterococci to aminoglycosides and glycopeptides ,Clinical Infectious Diseases. 15,495-501.

Lim, S. ; Tanimoto, K. ; Tomita, H. ; Ike , Y. (2006). Pheromone - responsive conjugative vancomycin resistance plasmids in Enterococcus faecalis isolated from humans and chicken feces , Applied and Environmental Microbiology. 72,6544-6553.

Migura, L. ; Hasman, H. ; Jensen, L. (2009). Presence of pRI1: a small cryptic mobilizable plasmid isolated from Enterococcus faecium of human and animal origin , Current Microbiology .58,95-100.

Olsen, J. ; Brown, D. ; Baggesen, D. ; Bisgaard, M. (1992). Biochemical and molecular characterization of Salmonella entrica Serovar berta , and comparision of methods for typing, Epidemiology and Infection. 108,243-260. 
Tomita, H. ; Ike , Y. (2005). Genetic analysis of transfer- related regions of the vancomycin resistance Enterococcus conjugative plasmid $\mathrm{pHT} \beta$ : Identification of OriT and a putative relaxase gene, J. Bacteriol. 187, 7727-7737.

Zheng, B. ; Tomita , H. ; Inoue, T. ; Ike, Y. (2009). Isolation af Van B- type Enterococcus faecalis strains from nosocomial infections : First report of the isolation and identification of the pheromone - responsive plasmids pMG2200, encoding Van B- type vancomycin resistance and a Bac41- type bacteriocin, and pMG2201 , encoding erythromycin resistance and cytolycin (Hly/Bac), Antimicrobial Agents and Chemotherapy. 53, 735-747. 